\title{
Assessment on Corrosion Damage of Steel Reinforced Concrete Structures of Kathmandu Valley Using Corrosion Potential Mapping Method
}

\author{
Nav Raj Phulara, Jagadeesh Bhattarai ${ }^{1}$ \\ Central Department of Chemistry, IOST, Tribhuvan University, Kirtipur, Kathmandu, Nepal \\ ${ }^{1}$ Corresponding author: bhattarai_05@yahoo.com
}

Received: Dec 15, 2018

Revised: April 04, 2019

Accepted: April 07, 2019

\begin{abstract}
Present study is focused to investigate the corrosion damage conditions of steel reinforced twenty eight different types of the concrete structure samples from Kathmandu valley using a non-destructive technique of the corrosion potential mapping (CPM) method in accordance with ASTM C876-91 Standards. It is found from the present assessment that the building roof of public owners house, hume pipes and building pillars used in Kathmandu valley are generally under the low risk of reinforced steel corrosion in these concrete structures, that is, less than $10 \%$ probability of the corrosion damage, although the fencing pillars and the roof slabs of different office buildings are found to be high risk of reinforced steel corrosion damage, that is, more than $90 \%$ probability of corrosion damage among twenty eight concrete structures.
\end{abstract}

Keywords: Rebar, concrete damage, corrosion potential, voltmeter, saturated calomel electrode

\section{Introduction}

The steel reinforced concrete structures are one of the most widely used materials of construction in manufacturing plants, highway infrastructures, buildings, tunnels and so on due to its versatility and acceptability. Strong alkaline nature of the concrete with $\mathrm{pH}$ between 12.5 and 13.5 generally protects the reinforced steel in concrete structures from their corrosion damages, although the concrete begins to corrode when chloride, sulfate or carbon dioxide mainly ingresses $[3,4,19]$. The reinforced steel in concrete are passivated by the formation of iron oxide film (i.e. $\mathrm{Fe}_{2} \mathrm{O}_{3}$ ) that provides a protective layer to the reinforced steel in high-alkalinity environment of the concrete structures [19]. In this state, the concrete normally provides the protection of the reinforcing steels. However, concrete block develops minute pores during hardening which become potential source for the ingress of corrosive agents like carbon dioxide, chlorides, sulfides and so on into the steel reinforced concrete structures. These corrosive agents, entering into the concrete through the pores, leads to the breakdown of the passive layer formed on the surface of the reinforced steel of the concrete structures. The corrosion of the reinforced steel in concrete structure is able to commence at high rate when the passive film formed on the steel surface is broken down. It was reported that 
such phenomena of the breakdown of the passive film formed on the reinforced steel occurs either by a decrease in $\mathrm{pH}$ value $(\mathrm{pH}<10)$ of the concrete environment due to carbonation or by presence of chloride salts, which initiates an expansive corrosion of the reinforced steel and eventually damages the surrounding concrete blocks [13].

Corrosion of the reinforced steel in concrete reduces the life and durability of concrete structures. For example, the annual direct cost of corrosion for highway bridges is estimated to be $\$ 13.6$ billion all over the world and only in USA the direct annual cost of repair and replacement of deficient concrete bridges was estimated around US\$ 8.3 billion or $0.095 \%$ of the gross domestic product (GDP) of that country $[12,13]$. A similar survey conducted in Japan and it was estimated the corresponding expenditure of JP $¥ 177.4$ billion or $0.059 \%$ of the 1999 GDP of that country [15]. In Britain, the total estimated cost for the rehabilitation and repair of deficient concrete bridges was reported to be $£ 616.5$ million spread over a period of ten years and this would amount to about $0.013 \%$ of the 1989 GDP of the UK [24]. It is also estimated that indirect costs, such as traffic delays and subsequent lost productivity, can amount to ten times the value of direct costs [23]. Cost of corrosion studies have been undertaken by several other countries including, Australia, China, Finland, Germany, India, Kuwait and Sweden and the common finding of these studies was that the annual corrosion costs of such concrete structures ranged from approximately 1 to $5 \%$ of the GDP of each nation [15].

A non-destructive technique of the CPM method is generally applied on the steel reinforced concrete structures to identify the spots of undergoing corrosion on the surface of the reinforced steel in concrete structures. The corrosion status of the reinforced steel is related with the measured open circuit corrosion potential (OCCP) value in the CPM method and this technique does not give the information of the corrosion kinetics. There are two types of CPM methods; they are more frequently used half-cell or OCCP test method and rarely used double-probe corrosion potential test method to monitor the corrosion damage of the steel reinforced concrete structures. The OCCP method was used in this research work and the OCCP value was measured at several distinct points over a given area of the steel reinforced concrete structures to be surveyed, and is used as a qualitative index for ascertaining whether the steel reinforced in concrete structures are likely to be corroded or not.

The corrosion potential mapping survey can qualitatively indicate whether the reinforced steel in concrete structures is corroded or not in accordance with ASTM C876-91 standards [2]. The range of potential value that signifies high or low corrosion risks of the reinforced steel in concrete structures were studied in previous research works [16-19, 21]. It was developed software for interpreting the measured corrosion potential data to assess the condition of the reinforced steel in concrete structures [18]. Effect of oxygen pressure on the corrosion of iron embedded in mortar with various chloride ion concentrations was recently examined using new hyperbaric-oxygen accelerated corrosion test (HOACT) and it was reported that the chloride ion should be necessary to initiate corrosion of reinforced iron in mortar which was enhanced in the pressurized oxygen gas [9]. However, when the oxygen pressure was supplied exceeded a certain level, the corrosion of the reinforced iron was reported to be suppressed due to formation of a protective passive film under the excessive supply of oxygen.

On the other hand, it was studied the effect of corrosion degree on the mechanical properties of 
reinforced steel in concrete and reported that the ductility of the steel bars was reported to be decreased with increasing corrosion level [1]. The corrosion risk of the steel reinforced concrete structures depends on the type of cement, for example, the cement with pozzolanic materials produced the pastes with a low quantity of calcium hydroxide and thus a low alkaline nature [6]. It was studied the effect of porosity and water content on the diffusivity of $\mathrm{CO}_{2}$ and $\mathrm{O}_{2}$ through hydrated cement paste and the result showed that the diffusivity of $\mathrm{CO}_{2}$ in concrete structures was found to be increased ten times when the water/cement ratio was increased from 0.4 to 0.8 and also the diffusivity of $\mathrm{CO}_{2}$ was lower than that of $\mathrm{O}_{2}$ [11]. Monitoring of open circuit corrosion potential, polarization resistance measurement and electrochemical impedance spectroscopy (EIS) were used to evaluate the corrosion behavior of reinforced steel in concrete using a non-destructive method [7]. It was reported that corrosion length on reinforced steel in concrete structures was reported to increase nonlinearly with increasing the crack width [14].

Numerous reinforced concrete structures such as bridges and offshore platforms are exposed worldwide to aggressive chloride environments and show evidence of corrosion after short service periods. For this reason, much research effort since the mid 1970s has addressed various techniques to prevent corrosion. Nevertheless, many existing structures have already a considerable amount of corrosion in progress. Recently, it was reviewed of research works which comparatively evaluated the laboratory and field toward identifying technically relevant situations where the use of sacrificial anodes may or may not be a practical option for reinforcement protection in concrete structures $[8,21]$. Influences of concrete cover, chloride content, compressive strength and moisture content on the half-cell potential measurement in reinforced concrete structure was studied and the results reported that the half-cell potential decreased when chloride content and moisture content increased and it was found to be increased when compressive strength increased [25].

Lots of concrete structures were damaged and more than ten thousand people were died in Nepal by the Great Earthquake-2015. Most of the Kathmandu people thought that they have strong concrete structures that will not be damaged easily, but the situation was found to be different after the earthquake. Engineers, technologists or scientists did not have time to think about the dangers from the corroded concrete structures and they did not have any awareness about the matters that whether the steel reinforced concrete structures people used are safe or not due to its corrosion damages. Foreign researchers and technologists were in need to check and identify the problem behind the unexpected damages of the concrete structures by the earthquake particularly in Kathmandu valley. In this context, this research works try to identify the situation of our concrete structures of Kathmandu valley in sense of corrosion damages using CPM method in accordance with the ASTM standards.

\section{Experimental Methods}

The corrosion behavior of twenty eight steel reinforced different types of concrete structures of Kathmandu valley were studied by measuring their OCCP to find out their corrosion damage condition using corrosion potential mapping CPM method in accordance with ASTM C876-91 standards [2] after visual inspection. These twenty eight steel reinforced concrete structures were selected randomly and classified into four main groups as: building roof, building pillar, hume pipe and fencing pillar. The details about the physico-morphological properties of these steel reinforced different types of the concrete structures were studied before their OCCP measurement. 
In the CPM method, the corrosion conditions of the reinforced concrete structures is ascertained with the help of the recorded corrosion potential value in accordance with ASTM C876-91 standards as given in Table 1 [2]. According to the ASTM C876-91 standards, if OCCP value over an area is more positive than $-126 \mathrm{mV}$ vs SCE, the corrosion risk of the reinforced steel in concrete structure should be very low corrosion, i.e., less than $10 \%$ corrosion risk at the time of measurement, and the corrosion activity of the reinforced steel in the measured concrete structures at the potential area is uncertain if the measured OCCP value is in the range of -276 to $-126 \mathrm{mV}$ vs SCE. Similarly, if the measured OCCP is more negative than $-276 \mathrm{mV}$ vs SCE then there is high corrosion, i.e., more than $90 \%$ corrosion risk of the reinforced steel corrosion at the time of measurement as summarized in Table 1 [2]. The OCCP of the reinforced steel in different types of concrete structures was measured by Voltmeter using saturated calomel electrode (SCE) and the exposed part of the reinforced steel of the concrete structures as reference and working electrode, respectively. The saturated calomel electrode was connected to the negative terminal and the reinforcing steel was connected to the positive terminal of the Voltmeter for the measurement of the OCCP values.

Table 1: OCCP value and corrosion condition of steel reinforced concrete structures [2]

\begin{tabular}{|l|l|l|}
\hline \multicolumn{2}{|l|}{ Open circuit corrosion potential (OCP) value } & \multirow{2}{*}{ Corrosion condition } \\
\hline $\mathrm{mV}$ vs CSE & $\mathrm{mV}$ vs SCE & \\
\hline$<-350$ & $<-276$ & High $(>90 \%$ risk of corrosion $)$ \\
\hline-350 to -200 & -276 to -126 & Uncertain \\
\hline$>-200$ & $>-126$ & Low $(<10 \%$ risk of corrosion $)$ \\
\hline
\end{tabular}

\section{Results and Discussion}

Twenty eight sampling sites of Kathmandu valley were randomly chosen to study the corrosion damage conditions of the steel reinforced concrete structure used for different purposes using CPM method. The details about the physical and morphological properties of these twenty eight steel reinforced concrete structures are tabulated in Tables 2, 3, 4 and 5 and also tabulated their OCCP values also. Four points (i.e., Pt-1, Pt-2, Pt-3 and Pt-4) of each sampling sites of the concrete structures were fixed to monitor their OCCP values. Among eleven sampling sites of the building roof category, four building roofs (i. e., TU Building-1, TU Building-2, TU Building-3 and Sanothimi) show the uncertain condition of the reinforced steel corrosion of the concrete structure having the recorded OCCP values ranges from -133 to $-196 \mathrm{mV}$ vs SCE except two points as shown in Table 2. However, the recorded OCCP values of the remaining seven building roofs are found in the range of $-30 \mathrm{mV}$ to $-125 \mathrm{mV}$ vs SCE, except one point indicates that more than 61 $\%$ of the steel reinforced building roof concrete structures, which are mostly of public people' buildings, used in this study, are found to be less than $10 \%$ risk of corrosion damage based on the classification of ASTM C786-91 Standards [2]. Remaining building roof concrete structures, which are of office buildings, indicate the uncertain condition of corrosion damage as shown in Fig. 1 also. 


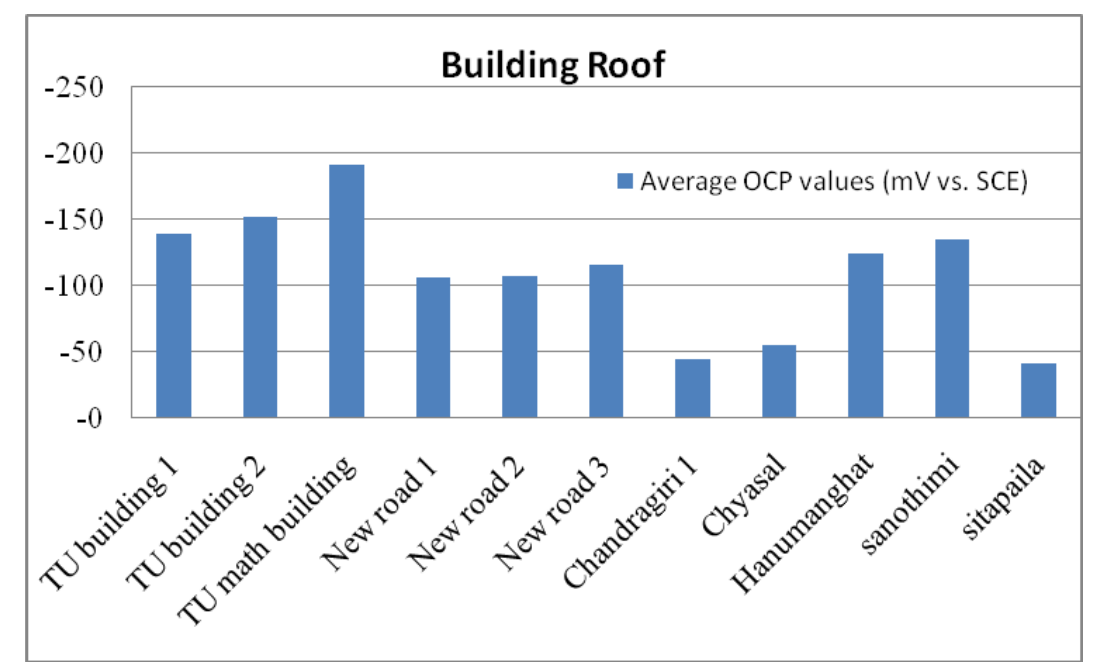

Fig. 1: OCCP values of the steel reinforced concrete building roof of different places

Table 2: OCCP data of the steel reinforced building roof concrete structure of Kathmandu valley

\begin{tabular}{|c|c|c|c|c|c|c|c|}
\hline \multicolumn{8}{|c|}{ Building Roof } \\
\hline \multirow{2}{*}{$\begin{array}{c}\text { S. } \\
\text { No. }\end{array}$} & \multirow{2}{*}{$\begin{array}{l}\text { Sampling } \\
\text { Site Name }\end{array}$} & \multirow{2}{*}{$\begin{array}{c}\text { Physical } \\
\text { Description }\end{array}$} & \multicolumn{5}{|c|}{$O C C P(m V v S S C E)$} \\
\hline & & & Pt-1 & Pt-2 & Pt-3 & Pt-4 & Remarks \\
\hline 1 & TU Building-1 & $\begin{array}{l}\text { new; smooth surface; no } \\
\text { cracking \& spalling; moist }\end{array}$ & -161 & -146 & -150 & -100 & Uncertain \\
\hline 2 & TU Building-2 & $\begin{array}{l}\text { new; smooth surface; no } \\
\text { cracking \& spalling; moist }\end{array}$ & -170 & -146 & -158 & -134 & Uncertain \\
\hline 3 & TU Building-3 & $\begin{array}{l}\text { new; smooth surface; no } \\
\text { cracking \& spalling; moist }\end{array}$ & -194 & -196 & -191 & -187 & Uncertain \\
\hline 4 & Newroad-1 & $\begin{array}{l}\text { new; smooth surface; no } \\
\text { cracking \& spalling; moist }\end{array}$ & -116 & -107 & -107 & -96 & $\begin{array}{c}\text { Low }(<10 \% \text { risk } \\
\text { of corrosion) }\end{array}$ \\
\hline 5 & Newroad-2 & $\begin{array}{l}\text { new; smooth surface; no } \\
\text { cracking \& spalling; moist }\end{array}$ & -95 & -107 & -108 & -119 & $\begin{array}{c}\text { Low }(<10 \% \text { risk } \\
\text { of corrosion })\end{array}$ \\
\hline 6 & Newroad-3 & $\begin{array}{l}\text { new; smooth surface; no } \\
\text { cracking \& spalling; moist }\end{array}$ & -120 & -103 & -117 & -125 & $\begin{array}{c}\text { Low }(<10 \% \text { risk } \\
\text { of corrosion) }\end{array}$ \\
\hline 7 & Chandragiri-1 & $\begin{array}{l}\text { old; smooth surface; no } \\
\text { cracking \& spalling; wet }\end{array}$ & -53 & -63 & -41 & -21 & $\begin{array}{c}\text { Low }(<10 \% \text { risk } \\
\text { of corrosion) }\end{array}$ \\
\hline 8 & Chyasal & $\begin{array}{l}\text { old; smooth surface; no } \\
\text { cracking \& spalling; wet }\end{array}$ & -38 & -53 & -42 & -89 & $\begin{array}{c}\text { Low }(<10 \% \text { risk } \\
\text { of corrosion) }\end{array}$ \\
\hline 9 & Hanumanghat & $\begin{array}{l}\text { new; smooth surface; no } \\
\text { cracking \& spalling; moist }\end{array}$ & -124 & -118 & -125 & -130 & Uncertain \\
\hline 10 & Sanothimi & $\begin{array}{l}\text { new; smooth surface; no } \\
\text { cracking \& spalling; moist }\end{array}$ & -133 & -122 & -141 & -146 & Uncertain \\
\hline 11 & Sitapaila & $\begin{array}{l}\text { new; smooth surface; no } \\
\text { cracking \& spalling; moist }\end{array}$ & -42 & -59 & -30 & -33 & $\begin{array}{c}\text { Low }(<10 \% \text { risk } \\
\text { of corrosion) }\end{array}$ \\
\hline
\end{tabular}


Fig. 2 showed the OCCP values for different building pillars at different places as tabulated in Table 3 also. All the recorded OCCP values of these seven building pillar of the steel reinforced concrete structures are in between $-92 \mathrm{mV}$ to $-141 \mathrm{mV}$ vs SCE and about $85 \%$ of the sampling sites of the steel reinforced building pillar structures, except Satdobato and Gwarko, have less than $10 \%$ corrosion risk. The corrosion condition of the steel reinforced building pillar of Satdobato and Gwarko samplings sites was found to be uncertain corrosion condition based on the ASTM Standards [2].

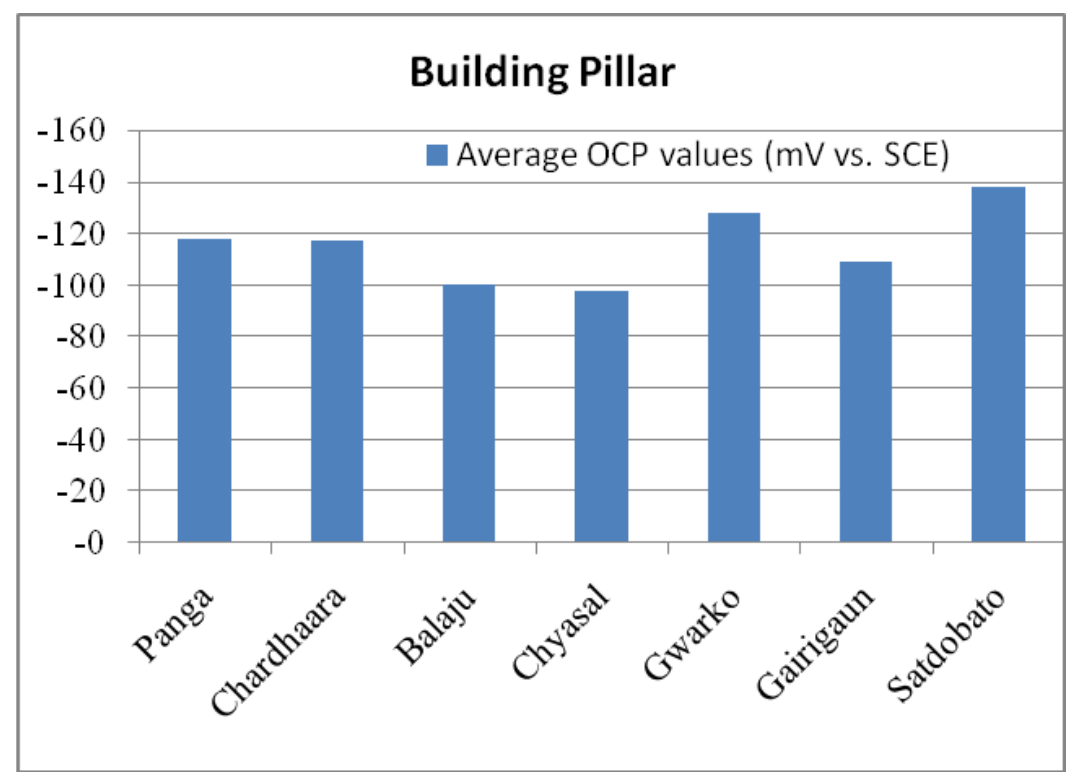

Fig. 2: OCCP values of the steel reinforced concrete building pillar of different places

Table 3: OCCP data of the steel reinforced building roof concrete structure of Kathmandu valley

\begin{tabular}{|c|c|c|c|c|c|c|c|}
\hline \multicolumn{1}{|l|}{ Building Pillar } \\
\hline $\begin{array}{c}\text { S. } \\
\text { No. }\end{array}$ & $\begin{array}{c}\text { Sampling } \\
\text { Site Name }\end{array}$ & $\begin{array}{c}\text { Physical } \\
\text { Description }\end{array}$ & Pt-1 & Pt-2 & Pt-3 & Pt-4 & Remarks \\
\hline 12 & Pangaa & $\begin{array}{c}\text { new; smooth surface; no } \\
\text { cracking \& spalling; dry }\end{array}$ & -114 & -130 & -108 & -119 & $\begin{array}{c}\text { Low }(<10 \% \text { risk } \\
\text { of corrosion) }\end{array}$ \\
\hline 13 & Chardhaara & $\begin{array}{c}\text { new; smooth surface; no } \\
\text { cracking \& spalling; dry }\end{array}$ & -120 & -109 & -123 & $*$ & $\begin{array}{c}\text { Low }(<10 \% \text { risk } \\
\text { of corrosion) }\end{array}$ \\
\hline 14 & Balaju & $\begin{array}{c}\text { new; smooth surface; no } \\
\text { cracking \& spalling; dry }\end{array}$ & -98 & -102 & -95 & -105 & $\begin{array}{c}\text { Low }(<10 \% \text { risk } \\
\text { of corrosion) }\end{array}$ \\
\hline 15 & Chyasal & $\begin{array}{c}\text { old; smooth surface; no } \\
\text { cracking \& spalling; dry }\end{array}$ & -92 & -94 & -97 & -108 & $\begin{array}{c}\text { Low }(<10 \% \text { risk } \\
\text { of corrosion) }\end{array}$ \\
\hline 16 & Gwarko & $\begin{array}{c}\text { new; smooth surface; no } \\
\text { cracking \& spalling; dry }\end{array}$ & -116 & -130 & -129 & -137 & Uncertain \\
\hline 18 & Satdobato & $\begin{array}{c}\text { old; smooth surface; no } \\
\text { cracking \& spalling; dry }\end{array}$ & -141 & -132 & -140 & -138 & Uncertain \\
\hline
\end{tabular}

* No data; Pt-1, Pt-2, Pt-3 \& Pt-4 are measurement points of same sampling site 
On the other hand, Fig. 3 shows the OCCP values of three different Hume pipes at different places of Kathmandu valley and they showed that these pipes have only less than $10 \%$ corrosion risk of the steel reinforced steel in concrete structures in accordance with the ASTM C786-91 Standard [2], because the recorded OCCP values of these three hume pipes are between $-8 \mathrm{mV}$ and $-64 \mathrm{mV}$ vs SCE as Tabulated in Table 4.

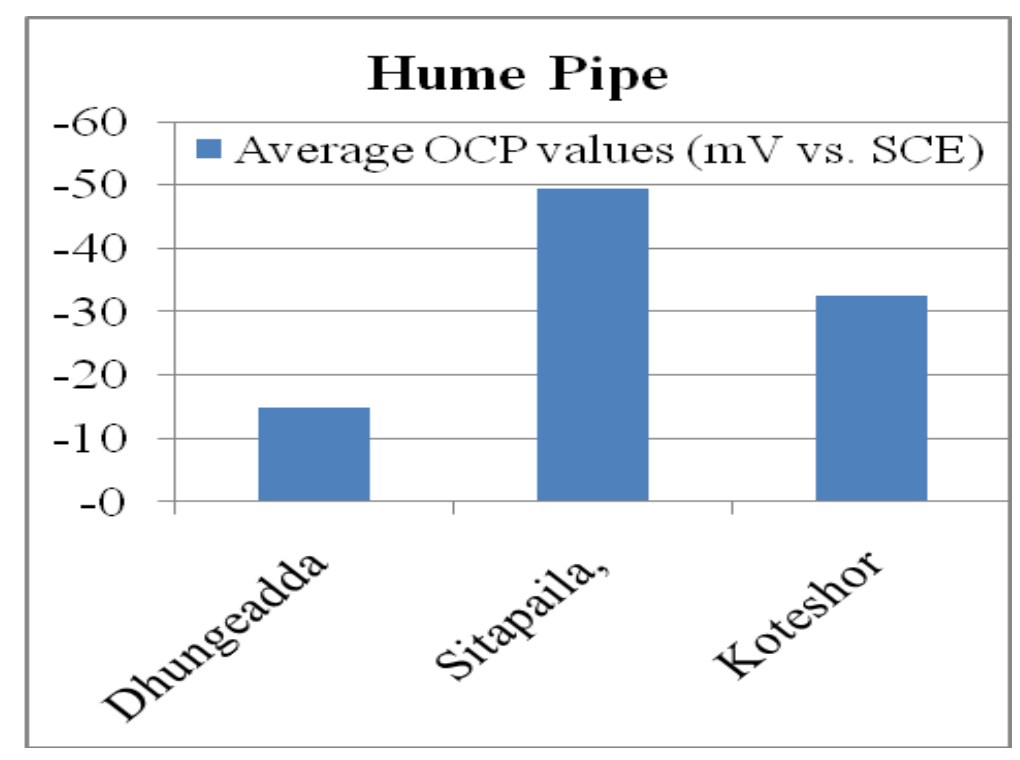

Fig. 3: OCCP values of the steel reinforced hume pipe of different places of Kathmandu valley

Table 4: OCCP of the steel reinforced hume pipes of Kathmandu valley

\begin{tabular}{|c|c|c|c|c|c|c|c|}
\hline \multicolumn{8}{|c|}{ Hume Pipe } \\
\hline$S$ & Sampling & Physical & \multicolumn{5}{|c|}{$O C C P(m V v s S C E)$} \\
\hline No. & Site Name & Description & Pt-1 & Pt-2 & $\mathrm{Pt}-3$ & Pt-4 & Remarks \\
\hline 19 & $\begin{array}{l}\text { Dhunge } \\
\text { Addaa }\end{array}$ & $\begin{array}{l}\text { new; smooth surface; no } \\
\text { cracking \& spalling; dry }\end{array}$ & -8 & -20 & -22 & -10 & $\begin{array}{c}\text { Low }(<10 \% \text { risk } \\
\text { of corrosion })\end{array}$ \\
\hline 20 & Sitapaila & $\begin{array}{l}\text { old; smooth surface; no } \\
\text { cracking \& spalling; moist }\end{array}$ & -64 & -53 & -37 & -44 & $\begin{array}{l}\text { Low }(<10 \% \text { risk } \\
\text { of corrosion })\end{array}$ \\
\hline 21 & Koteshwor & $\begin{array}{l}\text { old; smooth surface; no } \\
\text { cracking \& spalling; moist }\end{array}$ & -27 & -38 & -17 & -48 & $\begin{array}{c}\text { Low }(<10 \% \text { risk } \\
\text { of corrosion })\end{array}$ \\
\hline
\end{tabular}

Pt-1, Pt-2, Pt-3 \& Pt-4 are measurement points of same sampling site

Similarly, the OCCP values of seven sampling sites of the steel reinforced concrete structure of the fencing pillars are recorded between $-247 \mathrm{mV}$ and $-458 \mathrm{mV}$ vs SCE as tabulated in Table 5. The results indicate that all sampling point of these seven fencing pillars have more $90 \%$ corrosion risk as shown in Fig. 4, mostly due to more porous nature without smooth surfaces as compared with other sampled concrete structures analyzed in the present study. 


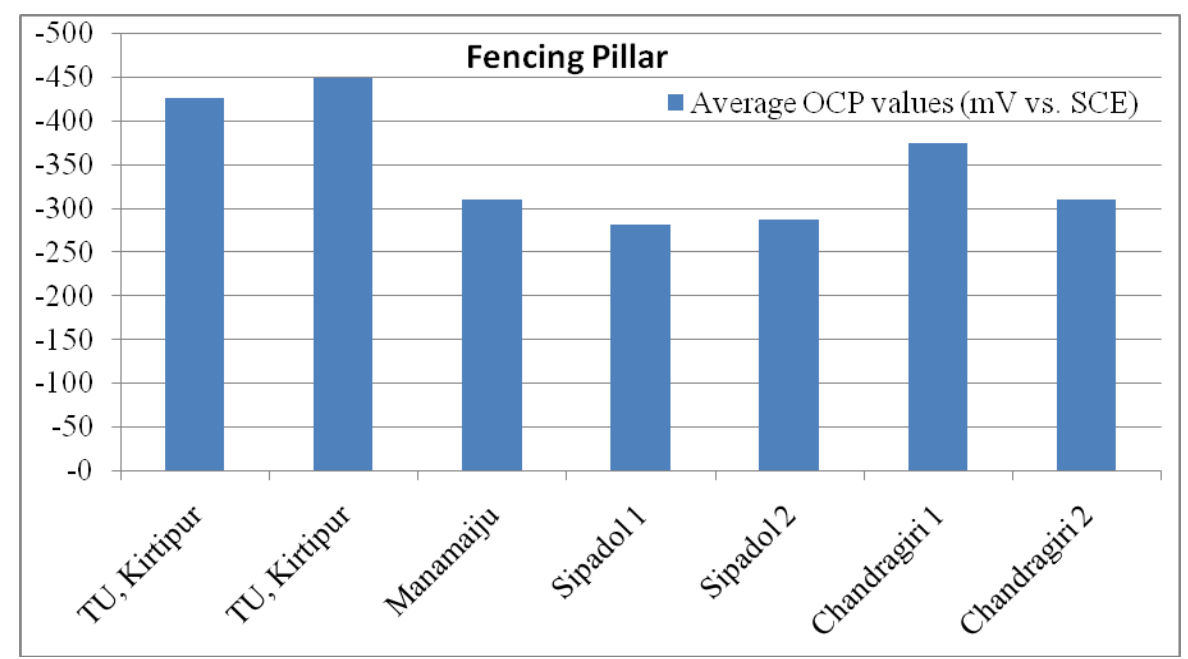

Fig. 4: OCCP values of the steel reinforced fencing pillar of different places of Kathmandu valley

Table 5: OCCP of the steel reinforced fencing pillar of Kathmandu valley

\begin{tabular}{|c|c|c|c|c|c|c|c|}
\hline \multicolumn{8}{|c|}{ Fencing Pillar } \\
\hline$S$. & Sampling & Physical & \multicolumn{5}{|c|}{$O C C P(m V v s S C E)$} \\
\hline No. & Site Name & Description & Pt-1 & Pt-2 & Pt-3 & Pt-4 & Remarks \\
\hline 22 & TU Kirtipur-1 & new; porous; spalling; moist & -415 & -409 & -443 & -435 & $\begin{array}{l}\text { High ( }>90 \% \text { risk } \\
\text { of corrosion) }\end{array}$ \\
\hline 23 & TU Kirtip & d; poro & -458 & 448 & -443 & -447 & $\begin{array}{l}\text { High ( }>90 \% \text { risk } \\
\text { of corrosion) }\end{array}$ \\
\hline 24 & Manamaiju & $\begin{array}{l}\text { old; porous; no cracking \& } \\
\text { spalling; dry }\end{array}$ & -312 & -288 & -347 & -290 & $\begin{array}{l}\text { High }(>90 \% \text { risk } \\
\text { of corrosion) }\end{array}$ \\
\hline 25 & Sipadol-1 & $\begin{array}{l}\text { old; porous; no cracking \& } \\
\text { spalling; dry }\end{array}$ & -247 & -302 & -291 & -284 & $\begin{array}{l}\text { High }(>90 \% \text { risk } \\
\text { of corrosion) }\end{array}$ \\
\hline 26 & Sipadol-2 & $\begin{array}{l}\text { new; porous; no cracking \& } \\
\text { spalling; moist }\end{array}$ & -298 & -250 & -269 & -327 & $\begin{array}{l}\text { High ( }>90 \% \text { risk } \\
\text { of corrosion) }\end{array}$ \\
\hline 27 & Chandragiri-1 & $\begin{array}{l}\text { old; porous; destructed; } \\
\text { moist }\end{array}$ & -412 & -377 & -429 & -280 & $\begin{array}{l}\text { High }(>90 \% \text { risk } \\
\text { of corrosion) }\end{array}$ \\
\hline 28 & Chandragiri-2 & $\begin{array}{l}\text { old; porous; destructed; } \\
\text { moist }\end{array}$ & -296 & -320 & -288 & -333 & $\begin{array}{l}\text { High }(>90 \% \text { risk } \\
\text { of corrosion) }\end{array}$ \\
\hline
\end{tabular}

Pt-1, Pt-2, Pt-3 \& Pt-4 are measurement points of same sampling site

\section{Conclusion}

The study concluded that the CPM method can use as an in-situ technique for assessing the corrosion monitoring of whole structures of the steel reinforced concrete very quickly. Hence, the method is a promising for predicting the accurate information on the corrosion status of the reinforced steel, 
whether it is in passive or active condition. From the present study, it can be concluded that the concrete structures which have rough surface with pores and cracks are under the high risk of the reinforced steel corrosion damages.

\section{References}

[1] Allmusallam AA (2001), Effect of degree of corrosion on the properties of reinforcing steel bars. Construction and Building Materials, 15(8): 361-368.

[2] ASTM C876-91 (1999), Standard test method for half-cell potentials of uncoated reinforcing steel in concrete, Annual Book of ASTM Standards, subcommittee G01.14, West Conshohocken, $1-6$.

[3] Bertolini L, Elsener B, Pedeferri P and Polder RP (2004), Corrosion of Steel in Concrete: Prevention, Diagnosis, Repair, Wiley-VCH Verlag GmbH \& Co., Weinheim.

[4] Bhattarai J (2010), Frontier of Corrosion Science, $1^{\text {st }}$ ed., Kshitz Publ., Kathmandu, Nepal.

[5] Biparva A (2016), Reinforced Concrete Corrosion: A Silent Killer, https://www. constructioncanada.net/reinforced-concrete-corrosion-a-silent-killer

[6] Castillo FDB, Roa-Rodríguez G, Cabrera CFC, Melo NS and Chapparo WAP (2015), Determination of the probability and rate of corrosion on reinforced concrete specimens through a remote corrosion monitoring system, TECCIENCIA, 10(19): 27-31.

[7] Choi YS, Kim JG and Lee KM (2006), Corrosion behavior of steel bar embedded in fly ash concrete, Corrosion Science, 48(7): 1733-1745.

[8] de Rincon OT, Torres-Acosta A, Sagüés A and Martinez-Madrid M (2018), Galvanic anodes for reinforced concrete structures: a review, Corrosion, 74(6): 715-723.

[9] Doi K, Hiromoto S, Katayama H and Akiyama E (2018), Effects of oxygen pressure and chloride ion concentration on corrosion of iron in mortar exposed to pressurized humid oxygen gas, Journal of the Electrochemical Society, 165(9): C582-C589.

[10] Dori J and Fisher RD Jr (2007), US and Asian Statistical Handbook 1999-2000, The Heritage Foundation, Washington.

[11] Houst YF and Wittmann FH (1994), Influence of porosity and water content on the diffusivity of $\mathrm{CO}_{2}$ and $\mathrm{O}_{2}$ through hydrated cement paste, Cement and Concrete Research, 24(6): 1165-1176.

[12] JACC (1999), Survey of Corrosion Cost in Japan, Japan Association of Corrosion Control, Japan.

[13] Johnston LD and Williamson SH (2005), The Annual Real and Nominal GDP for the United States, 1790 - Present, Economic History Services.

[14] Kim YY, Kim JM, Bang JW and Kwon SJ (2014), Effect of cover depth, w/c ratio and crack width on half-cell potential in cracked concrete exposed to salt spry condition, Construction and Building Materials, 54: 636-645.

[15] Koch GH, Thompson NG, Moghissi O, Payer JH and Varney J (2016), IMPACT-International Measures of Prevention, Application, and Economics of Corrosion Technologies Study, Report No. OAPUS310GKOCH (AP110272), NACE International, Houston, USA.

[16] Leelalerkiet V, Kyung J-W, Ohtsu M and Yokota M (2004), Analysis of half-cell potential measurement for corrosion of reinforced concrete, Construction and Building Materials, 18(3): 155-162.

[17] Page CL and Treadway KWJ (1982), Aspects of the electrochemistry of steel in concrete, Nature, 
297: 109-115.

[18] Parthiban T, Ravi R and Parthiban GT (2006), Potential monitoring system for corrosion of steel in concrete, Advances in Engineering Software, 37: 375-381.

[19] Revie RW and Uhlig HH (2008), Corrosion and Corrosion Control: An Introduction to Corrosion Science and Engineering, $4^{\text {th }}$ ed., John Wiley and Sons, Inc., New Jersey, USA.

[20] Ribeiro DV, Labrincha JA and Morelli MR (2012), Effect of the addition of red mud on the corrosion parameters of reinforced concrete, Cement and Concrete Research, 42: 124-133.

[21] Stefanoni M, Angst U and Elsener B (2018), Corrosion rate of carbon steel in carbonated concrete- a critical review, Cement and Concrete Research, 103: 35-48.

[22] Stratfull RF (1973), Half-cell Potentials and the Corrosion of Steel in Concrete, Washington, United States, Highway Research Board.

[23] TRB (1991), Highway Deicing, Comparing Salt and Calcium Magnesium Acetate. Transportation Research Board, National Research Council, Washington DC, Special Report 235.

[24] Wallbank EJ (1989), The Performance of Concrete in Bridges, a survey of 200 Highway Bridges, Her Majesty's Stationery Office, London.

[25] Yodsudjai W and Pattarakittam T (2017), Factors influencing half-cell potential measurement and its relationship with corrosion level, Measurement, 104: 159-168. 